\title{
ENERGY TRANSFER MECHANISMS IN
}

PHOTOBIOLOGICAL REACTIONS

FINAL REPORT

for Period I April 1960 - 31 March 1979

John D. Spikes

Department of Biology, University of Utah

Salt Lake City, Utah 84112

31 March 1979

Prepared For

THE U.S. DEPARTMENT OF ENERGY

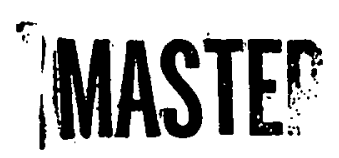

UNDER CONTRACT NO. EY-76-S-02-0875 


\section{DISCLAIMER}

This report was prepared as an account of work sponsored by an agency of the United States Government. Neither the United States Government nor any agency Thereof, nor any of their employees, makes any warranty, express or implied, or assumes any legal liability or responsibility for the accuracy, completeness, or usefulness of any information, apparatus, product, or process disclosed, or represents that its use would not infringe privately owned rights. Reference herein to any specific commercial product, process, or service by trade name, trademark, manufacturer, or otherwise does not necessarily constitute or imply its endorsement, recommendation, or favoring by the United States Government or any agency thereof. The views and opinions of authors expressed herein do not necessarily state or reflect those of the United States Government or any agency thereof. 


\section{DISCLAIMER}

Portions of this document may be illegible in electronic image products. Images are produced from the best available original document. 


\section{NOTICE}

This report was prepared as an account of work sponsored by the United States Government. Neither the United States nor the United States Department of Energy, nor any of their employees, nor any of their contractors, subcontractors, or their employees, makes any warranty, express or implied, or assumes any legal liability or responsibility for the accuracy, completeness, or usefulness of any information, apparatus, product or process disclosed or represents that its use would not infringe privately owned rights.

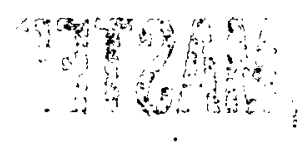


FINAL REPORT

Introduction

This report will be brief since essentially all of the research performed is described in the manuscripts, reprints and abstracts of papers presented at meetings as listed in the appendices. Copies of reprints and manuscripts have been submitted to DOE.

To our knowledge, we have complied fully with all contract requirements.

\section{Abstract of Research Acomplishments}

This project was concerned primarily with studies of the mechanisms of the sensitized photooxidation of selected biomolecules using a variety of photosensitizers. Such reactions are often termed photodynamic processes. In particular we have carried out steady-state kinetic studies, flash photolysis and spectral studies and product formation studies of the sensitized photooxidation of the five susceptible amino acids (cysteine, histidine, methonine, tryptophan and tyrosịne) and their derivatives, as well as purines and pyrimidines. A number of studies were also carried out on the mechanisms of the photodynamic inactivation of enzymes (trypsin, ribonuclease, lysozyme, etc.). Mechanism of photosensitization were studied using a variety of sensitizers including flavins, porphyrins and a number of synthetic dyes (substituted fluoresceins, acridines, thyazines, etc.).

\section{Summary of Other Accomplishments}

1. Publications. As listed in Appendix A, 58 papers were published (or have been submitted for publication) as a result of research carried out under this project.

2. Meetings. As listed in Appendix B, 120 papers based on this project were presented at local, national and international scientific meetings. A number 
weré presented by invitation.

3. Educational Activities. Fifteen students received Masters and Ph.D. degrees based on research carried out under this project. Included were Dwayne H. Curtis (Ph.D., 1963), Camillo A. Ghiron (Ph.D., 1964), Dennis C. Hall (M.S., 1964), Blaine W. Glad (Ph.D., 1964), Juli Y. Haga (Ph.D., 1967), Michael J. Wade (M.S., 1967), Ella B. McVey (M.A., 1967), Thomas R. Hopkins (Ph.D., 1967), Carol F. Hodgson Harner (Ph.D., 1969), Martha L. Preston Macknight (Ph.D., 1970), Larry A. Donoso (Ph.D., 1971), Dennis M. Wood (Ph.D., 1971), Frank Rizzuto (Ph.D., 1973), Yeou-Jan Kang (Ph.D., 1974), and Richard C. Straight (Ph.D., 1979).

All except one of the masters students subsequently obtained Ph.D. degrees at other institutions. Graduate students were co-authors of most of the papers published under this contract and also presented many of the papers at meetings.

Several postdocs and visiting scientists participated in the research program including Drs. Ali-Reza Mehran, John F. Bonner, Takashi Ito and Susan Poulter.

Finally, it should be stressed that much of the technical help used on the project was provided by undergraduate students in biology and chemistry working as part-time assistants.

\section{- Sumnary of Research Activities}

1. Photodynamic inactivation of enzymes. This represented a major part of our research effort under the contract. The mechanisms of the photodynamic inactivation of the following enzymes, as studied with several different sensitizers, was examined: trypsin $(A-8,9,11,12,14,20,21 ; B-8,10 ; 14,16,17,20,22$, $25,26,28,34,41,43)^{\star}$, chymotrypsin $(A-20,41 ; B-37,44,47,91)$, lysozyme $(A-24,28 ; B-47,54)$, ribonuclease $(A-27,29,40 ; B-63,66,69,77,94)$,

*Refers to published papers as listed in Appendix $A$ and to papers presented at meetings as listed in Appendix B. 
peroxidase $(A-45,46 ; B-85,90,98,105)$, and acetylhexosaminidase $(A-57 ; B-84)$. One of the most interesting findings in these studies was that the photodynamic inactivation of an enzyme was not necessarily mediated by the destruction of a sensitive amino acid residue(s) in the active site, but could also involve the destruction of residue(s) elsewhere resulting in a change in the enzyme molecule to an inactive conformation.

\section{Comparison of the sensitivity of enzymes to inactivation by ionizing} radiation and photodynamic treatment. The quantum yields of the photodynamic inactivation (with eosin Y, FMN and methylene blue as sensitizers) of acetylated trypsin, carboxypeptidase, catalse, alpha-chymotrypsin, beta-chymotrypsin, gamma-chymotrypsin, delta-chymotrypsin, lysozyme, papain, peroxidase, ribonuclease, subtilisin and trypsin were compared with the inactivation yields for the same enzymes by cobalt-60 gamma radiation (A-23; $B-11,30,39)$. The relative sensitivities to photodynamic treatment and gamma radiation were roughly the same for most of the enzymes. Some studies were also made of the relative sensitivities of amino acids in solution to the two kinds of treatment (B-57).

3. Chemical protection against photodynamic treatment. A rather detailed examination was made of the mechanisms by which photodynamic "protective agents" interfere with the photodynamic inactivation of enzymes $(A-14,21,24,43$; B-34, 39, 74, 86).

4. Sensitized photooxidation of amino acids. Since the photodynamic inactivation of enzymes results from the photooxidation of amino acid residues, a considerable amount of work was done on the mechanisms of the photooxidation of the susceptible amino acids using a number of different sensitizers $(A-48,52 ; B-23,29,32,46$, $62,72,76,78,88,92,95,99,104,108,110,115,119,120)$. In particular, the effects of various substituents on the sensitivity to photooxidation was 
examined.

5. Sensitized photooxidation of purines and pyrimidines. Studies similar to the amino acid work were carried out with purines and pyrimidines as substrates. In particular, the effect of different substituents in the 5-position of uracil was examined in terms of the sensitivity to and mechanism of the sensitized photooxidation using different sensitizers (B-49, 113, 114).

6. Sensitized photooxidation of tendon (collagen). Selective effects of different sensitizers and of reaction conditions on the photooxidation of amino acids in mammalian tendons was studied. Of considerable interest it was found that the photodynamic treatment of tendon induced the fornation of stable crosslinks which markedly altered some properties (shrinkage temperature, solubility in dilute acids, mechanical properties) of the tendon (A-7;B-27).

7. Photochemical properties of photodynamic sensitizers. Considerable work was done on the photochemical properties of several photodynamic sensitizers in order to establish what characteristics were most important in an efficient sensitizer. In particular, the effects of various substituents on xanthenes (fluoresceins) and porphyrins were examined $(A-35,44,47 ; B-73,74,80,81$, $83,86,89,92,97,102,106,107,109,111,116,120)$. Some work was also done to compare the sensitizing efficiencies of bound sensitizers and sensitizers free in solution $(B-96,100,110)$.

8. Miscellaneous photodynamic studies. Minor studies were made of photodynamic effects on isolated mitochondria $(A-37 ; B-35,43,48,68)$, on the aquatic annelid Tubifex (A-32; B-75), on Drosophila (B-59), on the antigenic properties of tumor cells $(B-61)$ and on the induction of mutations in bacteria. 


\section{APPENDIX A - PUBLICATIONS}

1. "Photosynthesis" (a review), by J. D. Spikes and B. C. Mayne. Ann. Rev. , Physical Chem. 11:501-530 (1960).

2. "Comparative kinetics of the photosynthesis and whole-cell Hill reaction of Chlorella," by J. D. Spikes and.G. N. Fasse11. pp. 471-473 In Progress in Photobiology (B. Chr. Christensen and B. Buchmann, editors), El sevier (1961).

3. "The mechanism of the photochemical activity of isolated chloroplasts. VI. Effects of heavy water on the kinetics of the Hill reaction", by J. S. Rieske, R. Lumry and J. D. Spikes. Arch. Biochem. Biophys. 97: 100-106 (1962).

4. "The significance of absolute configuration in optical rotation and catalysis," by H. Eyring, L. Jones, and J. D. Spikes. pp. 229-250, In Horizons in Biochemistry, edited by Kasha and Pul1man, Academic Press, Inc., 1962.

5. "Radiation effects and peaceful uses of atomic energy in the plant and soil sciences." J. D. Spikes In Radioecology, Proc. Ist National Symposium on Radioecology, pp. 5-11, edited by V. Schultz and A. W. Klement, Jr., Reinhold Publishing Corp. (1963).

6. "Effects of photodynamic treatment, ultraviolet radiation and gamma radiation on the photosynthesis and Hill reaction of Chlorella." J. D. Spikes and Dennis C. Hall In Photosynthes is Mechanisms in Green Plants, pp. 733-741, Publication 1145. National Academy of Sciences-National Research Council (1963).

7. "Photodynamic effects in biological systems." J. D. Spikes and C. A. Ghiron In Physical Processes in Radiation Biology, pp. 309-338. Academic Press, New York (1964). Edited by Augenstein, Mason and Rosenberg.

7a. "Photodynamic action." J. D. Spikes and B. W. Glad. Photochem. Photobiol. 3: $471-487$ (1964).

8. "The flavin-sensitized photoinactivation of trypsin." C. A. Ghiron and J. D. Spikes. Photochem. Photobiol. 4: 13-27 (1965).

9. "The photoinactivation of trypsin as sensitized by methylene biue and eosin Y." C. A. Ghiron and J. D. Spikes. Photochem. Photobiol. 4: 901-905 (1965).

10. "Some effects of ionizing radiation on the metabolism and growth of sugar beets." M. Stout and J. D. Spikes. J. Amer. Soc. Sugar Beet Tech. 13: .333-340 (1965).

11. "Disc electrophoresis of irradiated trypsin," by C. A. Ghiron, A. F. Ghiron and J. D. Spikes. Photochem. Photobiol. 5: 201-205 (1966).

12. "Quantumyierd studies of the dye-sensitized photoinactivation of trypsin," by B. W. Glad and J. D. Spikes. Radiation Research 27: 237-249 (1966). 
13. "Kinetic studies on the photodynamic inactivation of enzymes," by J. D. Spikes. pp. 823-838, In Radiation Research, ed. by G. Silini. North Holland Publishing Co., Amsterdam (1967).

14. "The effects of tyrosine and thyronine analogues on the dye-sensitized photoinactivation of trypsin." B. W. Glad, J. D. Spikes and L. F. Kumagai. Life Sciences 6: 201-207 (1967).

15. "Sensitized photochemical processes in biological systems", by J. D. Spikes and R. Straight. Ann. Rev. Phys. Chem. 18: 409-436 (1967).

16. "Denaturation of proteins in $8 \mathrm{M}$ urea as monitored by tryptophan fluorescence: chymotrypsin, chymotrypsinogen and some derivatives," by T. R. Hopkins and J. D. Spikes. Biochem. Biophys. Res. Commun. 28: 480-484 (1967).

17. "Photodynamic degradation of proteins," by J. D. Spikes and T. R. Hopkins. Studia Biophysica 3: 73-80 (1967).

18. "Photodynamic action," by J. D. Spikes. pp. 33-64, In Photophysiology Current Topics, Vol. III, (A. C. Giese, editor), Academic Press, New York (1968).

19. "Denaturation of proteins in $8 \mathrm{M}$ urea as monitored by tryptophan fluorescence: trypsin, trypsinogen and some derivatives," by T. R. Hopkins and J. D. Spikes. Biochem. Biophys. Res. Commun. 30: 540-545 (1968).

20. "The sensitivity to photodynamic inactivation of trypsin, chymotrypsin and their zymogens," by T. R. Hopkins and J. D. Spikes. Arch. Biochem. Biophys. 126: $969-970(1968)$.

21. "The inhibition of the dye-sensitized photoinactivation of trypsin using tyrosine and thyronine analogues," by B. W. Glad, J. D. Spikes and L. F. Kumagai. Experientia 243: 1002-1003 (1968).

22. "The molecular biology of photodynamic action: sensitived photoautoxidations in biological systems," by J. D. Spikes and R. Livingston. In, Advances in Radiation Biology (L. Augenstein, R. Mason and M. Zelle, editors), Vol. 3, pp. 29-127. Academic Press, New York (1969).

23. "Inactivation of crystalline enzymes by photodynamic treatment and gamma radiation," by T. R. Hopkins and J. D. Spikes. Radiation Res. 37: 253-260 (1969).

24. "The inhibition of the dye-sensitized photoinactivation of lysozyme using tyrosine and thyronine analogues," by B. W. Glad, J. D. Spikes and L. F. Kumagai. Proc. Soc. Expt1. Biol. Med. 131: 1278-1280 (1969).

25. "Enzyme inhibition by palladium chloride," by J. D. Spikes and C. F. Hodgson. Biochem. Biophys. Res. Comm. 35: 420-422 (1969).

26. "The effect of oxygen concentration on the quantum yields of the dyesensitized photoinactivation of enzymes," by C. F. Hodgson, E. B. McVey and J. D. Spikes. Experientia 25: 1021-1023 (1969). 
27. "Investigation of the quantum yield of the dye-sensitized photoinactivation of ribonuclease," by M. L. Macknight and J. D. Spikes. Experientia 2E: 255-256 (1970).

28. "Conformational changes of lysozyme during photodynamic inactivation," by T. R. Hopkins and J. D. Spikes. Photochem. Photobiol. 12: 175-184 (1970).

29. "The time-course of the destruction of amino acid residues during the photodynamic inactivation of ribonuclease A," by M. L. Macknight and J. D. Spikes. Boll. Chim. Farm. 109: 659-664 (1970).

30. "The dye-sensitized photooxygenation of proteins," by J. D. Spikes and M. L. Macknight. Annals N.Y. Acad. Sci. 171: 147-160 (1970).

31. "Photoinactivation of solid dye-enzyme system: Requirements of water molecules," by T. Ito. Curr. Mod. Biol. 3: 233-236 (1970).

32. "Investigation of the photosensitivity of Tubifex," by M. L. Macknight, D. M. Wood and J. D. Spikes. Proc. Utah Acad Sci. 47: 222-232 (1970).

33. "The dye-sensitized photooxidation of biological macromolecules: A survey," by J. D. Spikes and M. L. Macknight. In Photochemistry of Macromolecules (R. F. Reinuth, editor), Plenum Press, New York, pp. 67-83 (1970).

34. "Kinetics of the interaction of formaldehyde, acetaldehyde and acrolein with rat tail tendon," by D. H. Curtis and J. D. Spikes. pp. 551-566, In, Chemical Dynamics (J. O. Hirschfelder and D. Henderson, editors), WileyInterscience, New York (1971).

35. "The efficiency of halogenated fluoresceins as sensitizers for the photodynamic inactivation of trypsin," by M. J. Wade and J. D. Spikes.

Photochem. Photobiol. 14: 221-224 (1971).

36. "Photodynamic effects on molecules of biological importance: amino acids, peptides and proteins," by J. D. Spikes and M. L. MacKnight. In, Research Progress in Organic, Biological and Medicinal Chemistry (U. GaTTo and L. Santamaria, editors), Vol. 3, part I, pp. 124-136. North-Holland Publishing Co., Amsterdam (1972).

37. "Effects of photodynamic treatment on mitochondria" by J. Y. Haga and J. D. Spikes. In, Research Progress in Organic, Biological and Medicinal Chemistry (U. Gallo and L. Santamaria, editors), Vol. 3, part II, pp. 464-479. NorthHolland Publishing Co., Amsterdam (1972).

38. "The time-course of the destruction of amino acid residues during the photodynamic inactivation of ribonuclease $A$," by M. L. Macknight and J. D. Spikes. Pp. 23-28 In Research Symposiun, papers presented at the NATO International Advanced Study Institute on the Biological Effects of Visible Light, AlgheroSassari, Italy, September, 1969. Published in 1972.

39. "A pH-dependent binding of eosin $Y$ to ribonuclease $A$," by M. L. Macknight and J. D. Spikes. Curr. in Mod. Biol. 5: 20-24 (1972). 
40. "Conformation changes in ribonuclease during photodynamic inactivation," by T. R. Hopkins and J. D. Spikes. Radiation Research 51: 293-301 (1972).

41. "Conformational measurements on bovine trypsin and alpha chymotrypsin during photodynamic inactivation," by T. R. Hopkins and J. D. Spikes. Radiation Research 53: 315-325 (1973).

42. "Photodynamic oxidation not involving singlet oxygen," by $F$. Rizzuto and J. D. Spikes. In Progress in Photobiology, pp. 9-11 (G. O. Schenck, editor) Gesellschaft J. Lichtforschung, Frankfurt (1974).

43. "Chemical inhibition of the eosin-sensitized photooxidation of trypsin," by F. Rizzuto and J. D. Spikes. Radiation and Environ. Biophysics 12: $2.17-232(1975)$.

44. "Porphyrins and related compounds as photodynamic sensitizers," by J. D. Spikes. Annals N.Y. Acad. Sci. 244: 496-508 (1975).

45. "The porphyrin-sensitized photooxidation of horseradish apoperoxidase," by Yeou-Jan Kang and J. D. Spikes. Arch. Biochem. Biophys. 172: 565-573 (1976).

46. "Sensitized photooxidation of low spin horseradish peroxidase," by YeouJan Kang and J. D. Spikes. Biochem. Biophys. Research Commun. 74: 11601167 (1977).

47. "The effect of chemical structure on the photosensitizing efficiencies of porphyrins," by G. Cauzzo, G. Gennari, G. Jori and J. D. Spikes. Photochem. Photobiol. 25: 389-395 (1977).

48. "The eosin-sensitized photooxidation of substituted phenylaranines and tyrosines," by F. Rizzuto and J. D. Spikes. Photochem. Photobiol. 25: 465-476 (1977).

49. "Photosensitization," by J. D. Spikes. In The Science of Photobiology (K. C. Smith, editor), Plenum Press, New York, pp. 87-112 (1977).

50. "Photosensitization in biological systems," by J. D. Spikes. In Research in Photobioliogy (A. Castellani, editor), Plenum Press, New York, p $\overline{p .} 237-$ 233 (1977).

51. "Mapping the three-dimensional structure of proteins by photochemical techniques," by G. Jori and J. D. Spikes. Photochem. Photobiol. Revs. 3: 193-275 (1978).

52. "Sensitized photooxidation of amino acids: effects on the reactivity of their primary amino groups with fluorescamine and o-phthalaldehyde," by R. C. Straight and J. D. Spikes. Photochem. Photobiol. 27: 565-569 (1978).

53. "Fundamental aspects of photosensitization and photodynamic action," by J. D. Spikes. In International Symposium on Current Topics in Radiobiology and Photobiology (R. M. Tyrrell, editor), Academia brasileira de Ciencias, Rio de Janeiro, Brazil, pp. 53-59 (1978). 
54. "International conference on singlet oxygen and related species in chemistry and biology: Review and general discussion," by J. D. Spikes and H. M. Swartz. Photochem. Photobiol. 28: 921-933 (1978).

55. "Photodynamics in photomedicine," by J. D. Spikes. In Photomedicine: light in Disease and Therapy (J. D. Reagan, editor), Raven Press, New York (in press, 1979).

56. "Effects of hydrostatic pressure on the Hill reaction," by $\mathrm{R}$. C. Straight and J. D. Spikes. Submitted to Experientia, 1979.

57. "Sheep liver beta-N-acetylhexasaminidase: partial purification, characterization and photodynamic inactivation." Submitted to Enzyme, 1979. 
1. "Comparative kinetics of the photosynthesis and whole-cell Hill reaction of Chlorella," by J. D. Spikes and G. N. Fassell. Presented at the Third International Congress on Photobiology, Copenhagen, Denmark, 31 July 4 August, 1960.

2. "Effects of x-rays on solutions of chlorophylls," by R. W. Van Norman, R. B. Shafer and B. J. Rice. Presented at the meetings of the American Society of Plant Physiologists, Purdue University, Lafayette, Indiana, 27-31 August 1961.

3. "Radiation effects and the peacefur uses of atomic energy in the plant and soil sciences," by J. D. Spikes. Presented by invitation at the First Symposium on Radioecology held at Colorado State University, Fort Collins, 11-15 September 1961.

4. "The riboflavin-sensitized photoinactivation of trypsin," by C. A. Ghiron and J. D. Spikes. Presented at the meetings of the Utah Academy of Sciences, University of Utah, Salt Lake City, 27-28 October 1961.

5. "Further studies on the effects of ionizing radiation on chlorophyll solutions," by D. Hall and R. W. Van Norman. Presented at the meetings of the Utah Academy Sciences, University of Utah, Salt Lake City, 27-28 October. 1961.

6. "Preliminary studies of the effects of high hydrostatic pressure on biological systems," by R. C. Straight and J. D. Spikes. Presented at the meetings of the Utah Academy of Sciences, University of Utah, Salt Lake City, 27-28 October 1961.

7. "Inhibition of Chlorella photosynthesis and whole-cell $\mathrm{Hill}$ reaction by substituted ureas," by J. D. Spikes. Presented at the meetings of the Biophysical Society, Washington, D.C., 14-16 February 1962.

8. "The $\mathrm{pH}$-dependence of the riboflavin-sensitized photoinactivation of trypsin," by C. A. Ghiron and J. D. Spikes. Presented at the meetings of the Biophysical Society, Washington, D.C., 14-16 February 1962.

9. "The use of radiation as a tool in biology," by John D. Spikes. University . of Utah Sigma Xi Annual Distinguished Faculty Lecture, 5 March 1962.

10. "Enzyme concentration effects on the riboflavin-sensitized photoinactivation of trypsin," by C. A. Ghiron and J. D. Spikes. Presented at the meetings of the Radiation Research Society, Colorado Springs, 20-23 May 1962.

11. "A comparison of the effects of $\mathrm{pH}$ on the inactivation of trypsin by gamma and by photosensitized visible radiation," by J. D. Spikes and C. A. Ghiron. Presented at the Second International Congress of Radiation Research, Harrogate, England, 5-11 August 1962.

12. "Preliminary.studies of the chlorophyll-sensitized photoinactivation of enzymes," by C. A. Ghiron and J. D. Spikes. Presented at the meetings of the American Society of Plant Physiologists, University of Oregon, Eugene, August 1962 . 
13. "Heterogeneity of commercial proteolytic enzymes as observed with paper electrophoresis," by Ali Reza Mehran. Presented at the meetings of the Society of General Physiologists, Corvallis, Oregon, 26-29 August 1962.

14. "Disc electrophoresis of irradiated trypsin: a preliminary report," by C. A. Ghiron, Linda M. Brower and J. D. Spikes. Presented at the meetings of the Utah Academy of Sciences, Weber State College, Ogden, Utah, 9-10 November 1962.

15. "The effects of three types of fluorescent lamps on the growth and photochemical properties of sugar beet plants," by B. W. Glad, D. C. Hall and J. D. Spikes. Presented at the meetings of the Utah Academy of Sciences, Weber State College, Ogden, Utah, 9-10 November 1962.

16. "Total protein determinations on irradiated trypsin: a preliminary study," by Arlene F. Ghiron, C. A. Ghiron and J. D. Spikes. Presented at the meetings of the Utah Academy of Sciences, Weber State College, Ogden, Utah, 9-10 November 1962.

17. "The pH-dependence of trypsin photoinactivation as sensitized by methylene blue and riboflavin," by J. D. Spikes and C. A. Ghiron. Presented at the meetings of the Biophysical Society, New York City, 18-20 February 1963.

18. "Post-irradiation effects on the photosynthesis and Hill reaction of gammairradiated Chlorella," by D. C. .Hall and J. D. Spikes. Presented at the meetings of the Utah Academy of Sciences held at the University of Utah, Salt Lake City, 12-13 April 1963.

19. "Photodynamic effects in biological systems," by J. D. Spikes and C. A. Ghiron. Presented by invitation at the Symposium on Physical Processes in Radiation Biology, Michigan State University, 6-8 May 1963.

20. "Preliminary studies on the quantum yield of the photodynamic inactivation of trypsin by methylene blue," by J. D. Spikes and B. W. Glad. Presented at the meetings of the Society of General Physiologists, Woods Hole, Massachusetts, 3-6 September 1963.

21. "Effects of photodynamic treatment, ultraviolet radiation and gamma radiation on the photosynthesis and Hill reaction of Chlorella," by J. D. Spikes and D. C. Hall. 'Presented by invitation at the Symposium on Photosynthetic Mechanisms in Green Plants, Warrenton, Virginia, 14-18 0ctober 1963.

22. "Preliminary studies on the quantum yield of the photodynamic inactivation of trypsin by eosin Y," by B. W. Glad and J. D. Spikes. Presented at the meetings of the Utah Academy of Sciences, Utah State University, Logan, 8-9 November 1963.

23. "Sensitized photooxidation of histidine by some selected dyes," by R. C. Straight and J. D. Spikes. Presented at the meetings of the Utah Academy of Sciences, Utah State University, Logan, 8-9 November 1963.

24. "Photodynamic action," by J. D. Spikes. Presented by invitation at the NASNRC Conference on Molecular Mechanisms in Photobiology held at Wakulla Springs, Florida, 16-21 February 1964. 
25. "Observations on the disc electrophoresis of inactivated trypsin," by $C$. A. Ghiron and J. D. Spikes. Presented at the meetings of the Biophysical Society held in Chicago, Illinois, 26-28 February 1964.

26. "Quantum yield of methylene blue, eosin $Y$, and flavine mononucleotide photodynamic inactivation of trypsin," by J. D. Spikes and B. W. Giad. Presented at the meetings of the Biophysical Society. held in Chicago, I11., 26-28 February 1964.

27. "Effects of visible light on mammalian tendon in the presence of sensitizing dyes," by J. D. Spikes. Presented by invitation at the International Conference on Photosensitization in Solids held at the I17inois Institute of Technology, Chicago, 22-24 June 1964.

28. "The photodynamic inactivation of trypsin," by J. D. Spikes and B. W. Glad. Presented at the Fourth International Photobiology Congress, 0xford, England, 26-30 July 1964.

29. "Chlorophyll, chlorophyllin preparations and some selected dyes as sensitizers of the photooxidation of imidazole," by R. C. Straight and J. D. Spikes. Presented at the meetings of the American Society of Plant Physiologists, University of Colorado, Boulder, 24-27 August 1964.

30. "Gamma radiation inactivation of the enzyme trypsin: action of chemical protective agents," by D. M. Wood and J. D. Spikes. Presented at the meetings of the Utah Academy of Sciences held at the University of Utah, Salt Lake City, 13-14 November 1964.

31. "Quantum yields for the dye-sensitized photoinactivation of several purified enzymes," by T. R. Hopkins and J. D. Spikes. Presented at the meetings of the Utah Academy of Sciences held at the University of Utah, Salt Lake City, 13-14 November 1964.

32. "The dye-sensitized photooxidation of substituted imidazoles and indoles," by R. C. Straight and J. D. Spikes. Presented at the meetings of the Utah Academy of Sciences held at the University of Utah, Salt Lake City, 13-14 November 1964.

33. "Measurement of dye-sensitized photooxidation reactions with an oxygen electrode." R. C. Straight, J. D. Spikes and J. L. Lords. Presented at the meetings of the Biophysical Society, San Francisco, California, 24-26 February 1965.

34. "Effects of radiation protection agents on the inactivation of trypsin by photodynamic treatment and by gamma radiation." J. D. Spikes and D. M. Wood. Presented at the Pacific Slope Biochemical. Conference, Univ. of Southern California, Los Angeles, 1-3 September 1965.

35. "Effects of light on isolated rat liver mitochondria in the presence of methylene blue." Juli Y. Haga and J. D. Spikes. Presented at the meetings of the Utah Acad. of Sciences, Brigham Young University, Provo, 29 October 1965.

36. "The inhibition of trypsin by palladium chloride." Carol $F$. Hodgson and $J$. D. Spikes. Presented at the meetings of the Utah Academy of Sciences, Brigham Young University, Provo, 29 October 1965. 
37. "Conformational transitions in alpha-chymotryps in inactivated by photodynamic action." T. R. Hopkins and J. D. Spikes. Presented at the meetings of the Utah Academy of Sciences, Brigham Young University, Provo, 29 October 1965.

38. "Relative efficiency of substituted fluoresceins as photosensitizers:" M. J. Wade and J. D. Spikes. Presented at the meetings of the Utah Academy of Sciences, Brigham Young University, Provo, 29 October 1965.

39. "Inactivation of trypsin by photodynamic treatment and by gamma radiation: influence of radiation protective agents," by J. D. Spikes and D. M. Wood. Presented at the meetings of the Radiation Research Society, Coronado, California, 13-16 February 1966.

40. "Kinetic studies of the photodynamic inactivation of enzymes," by J. D. Spikes. Presented by invitation at the Third International Congress of Radiation Research, Cortina d'Ampezzo, Italy, June 26-July 2, 1966.

41. "Effect of gamma radiation on the binding of dyes by trypsin and alphachymotrypsin," by J. D. Spikes. Presented at the Third International Congress of Radiation Research, Cortina d'Ampezzo, Italy, June 26-july 2, 1966.

42. "The conformational changes of several photo-oxidized enzymes," by T.R. Hopkins and J. D. Spikes. Presented at the spring meeting of the American Chemical Society, Salt Lake Section, held at the University of Utah, 14 May 1966.

43. "Effects of photodynamic treatment on the metabolic activity of mitochondria isolated from rat liver," by Juli Y. Haga and J. D. Spikes. Presented at the meetings of the Utah Academy of Sciences held at the University of Utah, Salt Lake City, 4 November' 1966.

44. "A preliminary study on the effects of pH, dye concentration, and stirring on the quantum yield for the photodynamic inactivation of alpha-chymotrypsin," by Carol F. Hodgson and J. D. Spikes. Presented at the meetings of the Utah Academy of Science held at the University of Utah, Salt Lake City, 4 November. 1966.

45. "Kinetics of the fluorescence change of proteins in urea: A measure of conformational state," by T. R. Hopkins and J. D. Spikes. Presented at the meetings of the Utah Academy of Sciences held at the University of Utah, Salt Lake City, 4 November 1966.

46. "Effects of photooxidation on the difference spectra and fluorescence of amino acids, by R. Straight and J. D. Spikes. Presented at the meetings of the Utah Academy of Sciences, University of Utah, Salt Lake City, 4 November 1966.

47. "Conformational changes of alpha-chymotrypsin and lysozyme during photodynamic inactivation," by J. D. Spikes and T. R. Hopkins. Presented at the meetings of the Biophysical Society, Houston, Texas, 22-24 February 1967. 
48. "Effects of eosin $Y$-sensitized photodynamic treatment on isolated mitochondria," by Juli Y. Haga and J. D. Spikes. Presented at the meetings of the Federation of American Societies for Experimental Biology, Atlantic City, 16-21 April 1967.

49. "The dye-sensitized photooxidation of uracils as measured with an oxygen electrode," by J. D. Spikes. Presented at the meetings of the Radiation Research Society, San Juan, Puerto Rico, 7-11 May 1967.

50. "Photobiological reactions in plants and animals," by J. D. Spikes. Presented by invitation at the NATO Advanced Study Institute "Energetics and Mechanisms in Radiation Biology, "Portmeirion, Wales, 31 March-10 April 1967.

51. "A review of photodynamic action--dye sensitized photoautoxidation reactions in biological systems," by J. D. Spikes. Presented by invitation at the NATO Advanced Study Institute "Energetics and Mechanisms in Radiation Biology," Portmeirion, 31 March-10 April 1967.

52. "The photodynamic inactivation of enzymes: mechanisms not involving the catalytic centre," by T. R. Hopkins and J. D. Spikes. Presented at the NATO Advanced Study Institute "Energetics and Mechanisms in Radiation Biology," Portmeirion, Wales, 31 March-10 April 1967.

53. "Unfolding transitions of proteins in $8 \mathrm{M}$ urea as monitored by tryptophan fluorescence: trypsin, trypsinogen and DIP-trypsin," by T. R. Hopkins and J. D. Spikes. Presented at the meetings of the Utah Academy of Science, Utah State University, Logan, 21-22 Apri1 1967.

54. "Quantum yield studies of the photodynamic inactivation of lysozyme," by Ella B. Mcley and J. D. Spikes. Presented at the meetings of the Utah Academy of Sciences, Utah State University, Logan 21-22 Apri7 1967.

55. "The photodynamic degradation of proteins," by J. D. Spikes. Presented by invitation as one of the major introductory papers at the Fourth Jena Symposium entitled "Molecular Mechanisms of the Photodynamic Effect". held at the Institute for Microbiology and Experimental Therapy, Jena, Germany (DDR), 12-16 September 1967.

56. "A new method of measuring surface tryptophan residues in enzymes, " by T. R. Hopkins and J. D. Spikes. Presented at the meetings of the Utah Academy of Sciences held at Heber State College, Ogden, 8 September 1967.

57. "Comparative sensitivity of amino acids in solution to gamma radiation, ultraviolet radiation and photodynamic treatment," by J. D. Spikes and D. Wood. Presented at meetings of the Radiation Research Society, Houston, Texas, 21-25 April 1968.

58. "The oxygen dependence of the photodynamic inactivation of enzymes," by Carol F. Hodgson, Ella B. McVey and J. D. Spikes. Presented at the meeting of the Pacific Division, American Association for the Advancement of Science, Utah State University, Logan, 24-29 June 1968. 
59. "The dye-sensitized killing of Drosophila by visible light," by J. D. Spikes and Colleen S. Hoagland. Presented at the meeting of the Pacific Division, American Association for the Advancement of Science, Utah State University, Logan, 24-29 June 1968.

60. "A survey of current research on photodynamic action," by J. D. Spikes. Presented by invitation as the introductory lecture of a symposium entitled "Photodynamic Action" at the Fifth International Congress on Photobiology, Dartmouth College, Hanover, New Hampshire, 26-31 August 1968.

61. "Effects of photodynamic treatment on antigenicity of mouse tumor and tumor fractions," by R. Straight, J. D. Spikes and E. Englert, Jr. Presented at the Fifth International Congress on Photobiology, Dartmouth College, Hanover, New Hampshire, 26-31 August 1968.

62. "Preliminary studies of the dye-sensitized photooxidation of methionine," by J. D. Spikes. Presented at the meetings of the Biophysical Society, Los Angeles, California, 25-28 February 1969.

63. "Preliminary investigation of the photodynamic inactivation of ribonuclease," by M. L. Macknight and J. D. Spikes. Presented at the meetings of the Utah Academy, Logan, Utah, 11 April 1969.

64. "The photodynamic degradation of proteins: detection of altered residues," by D. M. Wood and J. D. Spikes. Presented at the meetings of the Utah Academy, Logan, Utah, 11 April 1969.

65. "The inhibition of alpha-chymotrypsin by heavy metals," by C. F. Hodgson and J. D. Spikes. Presented at the Northwest Regional Meeting of the American Chemical Society, Salt Lake City, Utah, 12-13 June 1969.

66. "Kinetics of the dye-sensitized photoinactivation of ribonuclease," by $M$. L. Macknight and J. D. Spikes. Presented at the Northwest Regional Mieeting of the American Chemical Society, Salt Lake City, Utah, 12-13 June 1969.

67. "Photodynamic effects on molecules of biological importance: amino acids, small peptides and proteins," by J. D. Spikes and M. L. Macknight.

Presented by invitation at the NATO Institute on Biological Effects of Visible Light, held at the University of Sassari, Sassari, Sardinia, Italy, 3-17 September 1969.

68. "Effects of photodynamic treatment on mitochondria," by J. Y. Haga and J. D. Spikes. Presented by invitation at the NATO Institute on Biological Effects of Visible Light, held at the University of Sassari, Sassari, Sardinia, Italy, 3-17 September 1969.

69. "Investigations on the dye-sensitized photoinactivation of ribonuclease $A$," by M. L. Macknight and J. D. Spikes. Presented at the NATO Institute on Biological Effects of Visible Light, held at the University of Sassari, Sassari, Sardinia, Italy, 3-17 September 1969. 
70. "The dye-sensitized photooxidation of biological macromolecules," by $\mathrm{J}$. D. Spikes and M. L. Macknight. Presented by invitation as part of a symposium Photochemistry of Macromolecules sponsored jointly by the Society for Applied Spectroscopy and the American Chemical Society, held at the Disneyland Hotel, Ontario, California, 6-10 October 1969.

71. "Dye-sensitized photo-oxygenation of proteins," by J. D. Spikes and M. L. Macknight. Presented by invitation at the International Conference on Singlet Molecular Oxygen and its Role in Environmental Sciences, held at the New York Academy of Sciences, New York City, 23-25 0ctober 1969.

72. "Preliminary studies of the effects of solvent composition on the dyesensitized photooxidation of methionine," by J. D. Spikes. Presented at the meetings of the Biophysical Society, Baltimore, Maryland, 25-27 February, 1970.

73. "Oxygen effects on the flash photolysis behavior of dyes," by G. D. Coker, F. Rizzuto and J. D. Spikes. Presented at the meetings of the Utah Academy, Salt Lake City, 10 April 1970.

74. "Preliminary studies of the effects of thyroxine congeners on the photochemistry of eosin Y," by F. Rizzuto, B. W."Glad and J. D. Spikes. Presented at the meetings of the Utah Academy, Salt Lake City, 10 Aprit 1970.

75. "Preliminary studies of Tubifex photosensitivity," by M. L. Macknight, D. M. Wood and J. D. Spikes. Presented at the meetings of the Utah Academy, Salt Lake City, 10 April 1970.

76. "The dye-sensitized photooxidation of methionine derivatives," by J. D. Spikes. Presented at the Fourth International Congress of Radiation Research, Evian, France, 29 June-4 July, 1970.

77. "Some features of the FMN-sensitized photooxidation of ribonuclease $A$ under acidic conditions," by M. L. Macknight and J. D. Spikes. Presented at the Fourth International Congress of Radiation Research, Evian, France, 29 June4 July, 1970.

78. "The dye-sensitized photooxidation of methionine and its derivatives: kinetics and product formation," by J. D. Spikes and M. L. Macknight. Presented at the Third IUPAC Symposium on Photochemistry, St. Moritz, Switzerland, 12-18 Juiy 1970.

79. "Introductory Lecture," by J. D. Spikes. Presented on a symposium entitled "Light and the quality of the environment" held as part of the First National Biological Congress, Detroit, Michigan, 6-10 November 1970.

80. "Photo-binding of flavin sensitizers to proteins and peptides," by M. L. Macknight and J. D. Spikes. Presented at the meeting of the Biophysical Society, New Orleans, 15-18 February 1971.

81. "Preliminary flash photolysis studies of dye-sensitized photooxidation," by F. Rizzuto and J. D. Spikes. Presented at the meetings of the Biophysical Society, New Orleans, 15-18 February 1971. 
82. "Peroxide production in photodynamic systems," by D. M. Wood and J. D. Spikes. Presented at the meetings of the Biophysical Society, New Orleans, 15-18 February. 1971.

83. "Fluorescence, phosphorescence and flash excitation triplet spectra of iron, magnesium, zinc and metal-free deuteroporphyrin IX," by G. D. Coker, B. F. Burnham and J. D. Spikes. Presented at the meetings of the Utah Academy, Logan, Utah, 10 September 1971.

84. "Human liver glycosidases," by L. Donoso and J. D. Spikes. Presented at the meetings of the Utah Academy, Logan, Utah, 10 September 1971.

85. "The dye-sensitized photooxidation of peroxidases: inactivation of the apoenzyme," by Yeou-Jan Kang and J. D. Spikes: Presented at the meetings of the Utah Academy, Logan, Utah, 10 September 1971.

86. "A flash photolysis investigation of the effects of photodynamic inhibitors on the triplet states of sensitizing dyes," by F. Rizzuto and J. D. Spikes. Presented at the meetings of the Utah Academy, Logan, Utah, 10 September 1971.

87. "Photodynamic action," by J. D. Spikes. Presented by invitation at a workshop entitled "Photoalteration of Pesticides, "held in Washington, D.C., 6-8 Aprit 1972, under the sponsorship of the U.S.A.E.C. and the U.S.D.A.

88. "Preliminary studies of the dye-sensitized photooxidation of substituted phenylalanines" by J. D. Spikes and F. Rizzuto. Presented at the meetings of the Radiation Research Society, Portland, Oregon, 14-18 May 1972.

89. "Flash photolysis studies of transient spectra of metal-free and $\mathrm{Zn}^{++}$ deuteroporphyrin-IX in aqueous solutions" by G. D. Coker and J. D. Spikes. Presented at the Northwestern Regional Meeting of the American Chemical Society, Corvallis, Oregon, 15-16 June 19.72.

90. "The prosthetic group in peroxidase as a protector against photodynamic action," by Yeou-Jan Kang and J. D. Spikes. Presented at the Pacific Slope Biochemical Conference, Davis, California, 21-23 June 1972.

91. "The time-cqurse of amino acid residue destruction during the photodynamic inactivation of alpha-chymotrypsin," by C. F. Harner. Presented at the Pacific Slope Biochemical Conference, Davis, California, 21-23 June 1972.

92. "A flash-photolysis study of the eosin $Y$-sensitized photooxidation of tyrosine and related compounds," by F. Rizzuto and J. D. Spikes. Presented at the Pacific Slope Biochemical Conference, Davis, California, 21-23 June 1972.

93. "Photodynamic oxidation not involving singlet oxygen," by J. D. Spikes. Presented by invitation as part of a symposium entitled "Photochemistry and Photodynamic Action" held as part of the Sixth International Congress on Photobiology, Bochum, Germany, 21-25 August 1972.

94. "Light-induced binding of flavin sensitizers to ribonuclease $A$," by M. L. Macknight. Presented at the Sixth International Congress on Photobiology, Bochum, Germany, 21-25 August 1972. 
95. "Mechanism of the dye-sensitized photooxidation of substituted phenylalanines," by J. D. Spikes and F. Rizzuto. Presented at the NATO Advanced Study Institute on Primary Molecular Events in Photobiology, held at Badia Fiesolana, Florence, Italy, 4-16 September 1972.

96. "Photodynamic effects on proteins using free and bound sensitizers," by J. D. Spikes. Presented by invitation at the Fifth Meeting of the Committee on Phototherapy in the Newborn, National Research Council Division of Medical Science, Washington, D.C.; 21-23 February 1973.

97. "Flash transients of metal-free deuteroporphyrin-IX in acid aqueous solution," by G. D. Coker and J. D. Spikes. Presented at the meetings of the Biophysical Society, Columbus, Ohio, 27 February-2 March 1973.

98. "The role of histidines in the photodynamic inactivation of horseradish peroxidase," by Yeou-Jan Kang and J. D. Spikes. Presented at the meetings of the Biophysical Society, Columbus, Onio, 27 February-2 March 1973.

99. "Mechanism of the sensitized photooxidation of methionine," by J. D. Spikes. Presented by invitation at the Instituto di Chimica Farmaceutica, University of Padova, Italy, 2 May 1973.

100. "Photodynamic action with free and bound sensitizers," by J. D. Spikes. Presented by invitation at the First International Lisbon Symposium on Fluorescence: Microscopy, Measurement and Photochemistry. Instituto Portugues de Oncologia de Francisco Gentil., Lisbon, Portugal, 24-25 May 1973.

101. "The scope of photobiology," by J. D. Spikes. Presented by invitation at the meetings of the American Society for Photobiology, Sarasota, Florida, 11-15 June 1973.

102. "Porphyrins and related compounds as photodynamic sensitizers," by J. D. Spikes. Presented by invitation at a New York Academy of Science conference entitled "The Biological Role of Porphyrins and Related Structures," 23-26 0ctober 1973.

103. "The scope of photobiology," by J. D. Spikes. Introductory lecture to a symposium entitled "The Biologic Effects of Photons." Presented by invitation at the meetings of the American Optical Society, Washington, D.C., 22-25 April 1974.

104. "Kinetics of the dye-sensitized photooxidation of amino acids, "by R. Straight and J. D. Spikes. Presented at the meetings of the American Society for Photobiology, University of British Columbia, Vancouver, 23-26 July 1974.

105. "The role of protein conformation in the photodynamic resistance of horseradish peroxidase," by Y.-J. Kang and J. D. Spikes. Presented at the meetings of the American Society for Photobiology, University of British Columbia, Vancouver, 23-26 July 1974. 
106. "Effect of sensitized photooxidation of amino acids on their reactivity with fluorescamine," by R. Straight, G. Lewis and J. D. Spikes. Presented at the meetings of the American Society for Photobiology, Louisville, Kentucky, 23 June 1975.

107. "Ruthenium coordination compounds as photosensitizers for biological systems," by J. D. Spikes. Presented at the Gordon Conference on Organic Photochemistry, Tilton School, New Hampshire, 1 August 1975.

108. "Quantum yield measurements of the porphyrin-sensitized photooxidation of amino acids in aqueous solution," by G. D. Coker, J. D. Spikes and B. F. Burnham. Presented at the meetings of the. Utah Academy of Sciences, College of Southern Utah, Cedar City, Utah, 24 October 1975.

109. "Tris (2,2'-bipyridine) ruthenium II chloride as a sensitizer for the photooxidation of amino acids and proteins," by J. D. Spikes. Presented at the annual meeting of the American Society for Photobiology, Denver, 16-20 February 1976.

110. "Sensitized photooxidation of amino acids by methylene blue and eosin $Y$ bound to strong ion exchange resins," by R. Straight and J. D. Spikes. Presented at the annual meeting of the American Society for Photobiolugy, Denver, 16-20 February 1976.

111. "Fundamentals of porphyrin photochemistry," by J. D. Spikes. Presented by invitation at the Gordon Conference on Chemistry and Biology of Pyrroles, Brewster Academy, Wol fborough, New Hampshire, 2-6 August 1976.

112. "Photosensitization in biological systems," by J. D. Spikes. Presented by invitation as the introductory lecture on a symposium entitled Photosensitized Reactions of Nucleic Acids and Proteins, held as part of the Seventh International Congress on Photobiology, Rome, Italy, 29 August3 September 1976.

113. "Effects of substituents in the 5-position on the photooxidation of uracil as sensitized by eosin Y and 3-methyl lumiflavin," by J. D. Spikes. Presented at the Seventh International Congress on Photobiology, Rome, Italy, 29 August-3 September 1976.

114. "Kinetics of the eosin Y sensitized photooxidation of substituted uracils," by.J. D. Spikes. Presented at the 5 th Annual Meeting of the American Society for Photobiology, San Juan, Puerto Rico, 11-15 May 1977.

115. "The role of superoxide radical in the flavin-sensitized photooxidation of amino acids," by J. D. Spikes. Presented at the International Congress on Singlet Oxygen and Related Species, Pinawa, Manitoba, Canada, 27-26 August 1977.

116. "Porphyrins as photodynamic sensitizers," by J. D. Spikes. Presented by invitation as part of a symposium entitled Biological Photosensitization at the meetings of the American Chemical Society, Chicago, I1linois, 28 August-2 September 1977. 
117. "Fundamental aspects of photosensitization and photodynamic action," by J. D. Spikes. Presented by invitation as the introductory talk on a symposium entitled Fundamental Photobiology, held as part of the Fourteenth International Congress on Radiology, Rio De Janeiro, Brazil, 23-29. October 1977.

118. "Primary photochemical events and their relation to photobiology," by J. D. Spikes. Presented by invitation at the Institute of Biophysics, Universidade Federal do Rio De Janeiro, Brazil, on 25 October 1977.

119. "A preliminary examination of the eosin-sensitized photooxidation of cysteine and related compounds," by J. D. Spikes and R. Straight. Presented at the 6th Annual Meeting of the American Society for Photobiology, University of Vermont, Burlington, 11-15 June 1978.

120. "The photooxidation of cysteine and related compounds as sensitized by eosin $Y$ and by cadmium sulfide," by J. D. Spikes and R. C. Straight. Presented at a Photooxidation Workshop, Texas Christian University, 20-21 November 1978. 